\title{
The relationship between the presence of extra $\alpha$-globin genes and blood cell traits in Altamurana sheep
}

\author{
Elisa Pieragostini ${ }^{a *}$, Ferruccio Petazzi $^{b}$, Aldo Di Luccia $^{c}$ \\ ${ }^{a}$ Department of Engineering and Management of the Agricultural, \\ Livestock and Forest Systems, University of Bari, \\ Via Amendola, 165/A, 70100 Bari, Italy \\ b Department of Animal Health and Well-being, University of Bari, \\ Provinciale per Casamassima km 3, 70010 Valenzano (BA), Italy \\ ${ }^{c}$ Department of Animal Production, University of Bari, \\ Via Amendola, 165/A, 70100 Bari, Italy
}

(Accepted 4 February 2003)

\begin{abstract}
Additional $\alpha$-globin genes in sheep might produce extra $\alpha$-globin chains and, consequently, the subject carrying triplicated $(\alpha \alpha \alpha)$ or quadruplicated $(\alpha \alpha \alpha \alpha)$ haplotypes may exhibit different hematological phenotypes when compared to the normal duplicated $(\alpha \alpha)$ homozygotes $(N N)$. Both $\alpha \alpha \alpha$ and $\alpha \alpha \alpha \alpha$ heterozygous $(N D)$ and $\alpha \alpha \alpha$ and $\alpha \alpha \alpha \alpha$ homozygous $(D D)$ individuals were obtained by selection and inbreeding. Chromatographic RP-HPLC analyses of the globin chains of 65 subjects $(15 \mathrm{DD}, 20 \mathrm{ND}$ and $30 \mathrm{NN})$ were performed. A highly significant linear regression $\left(r^{2}=0.967\right)$ of the $\alpha / \beta$ ratio on the number of $\alpha$-globin genes was found, and the $\alpha / \beta$ ratio ranged on average from 1.0 in $N N$ individuals to 1.2 in the $N D$ and 1.6 in the $D D$ subjects. Values for blood fell within the range of normality but were rather peculiar as a whole. When the erythrocytes of individuals carrying normal arrangements were compared with those of subjects with extra $\alpha$-genes, the latter had fewer erythrocytes that were bigger in size and had a higher $\mathrm{Hb}$ content and a greater osmotic fragility. This hematological picture is consistent with the existence of an unbalanced $\alpha / \beta$ ratio.
\end{abstract}

erythrocytes / hemoglobin / $\alpha / \beta$ ratio / endemic TBD

\section{INTRODUCTION}

In sheep, as in humans and most other mammals, there are two $\alpha$-globin genes $(I \alpha$ and $I I \alpha)$, which are expressed at different levels, the upstream gene being the most efficient [19]. The high polymorphism of Altamurana sheep

\footnotetext{
* Correspondence and reprints

E-mail: pierelis@agr.uniba.it
} 
Locus

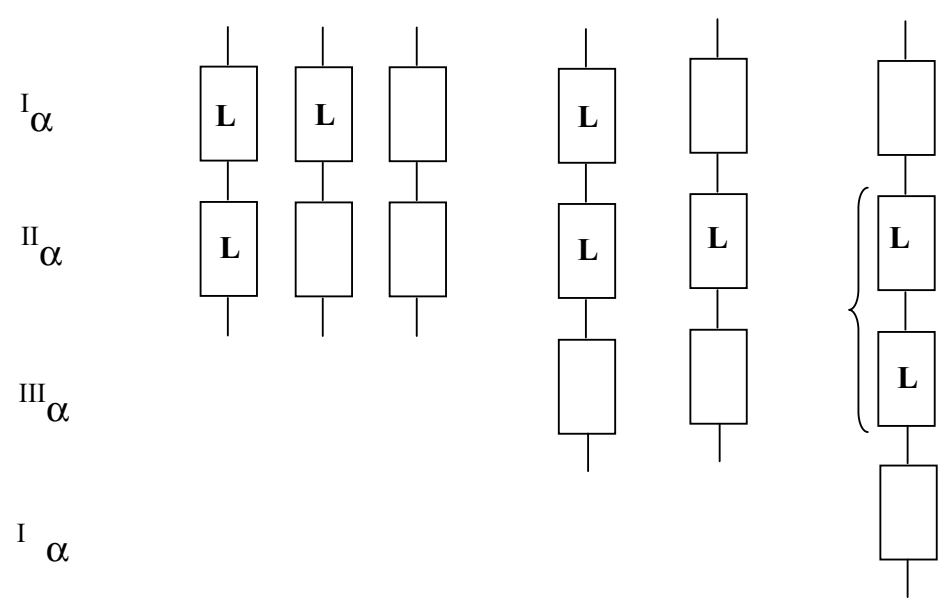

Figure 1. $\alpha$-globin gene haplotypes detected in sheep. The gene efficiency (\%) is indicated in parentheses. Alpha globin alleles are indicated by the capital letter corresponding to the relevant point mutation $(\mathrm{L}=113 \mathrm{Leu} ; \mathrm{H}=113 \mathrm{His} ; \mathrm{A}=8$ Ala, 113 Leu; D = 15 Gly, 113 Leu).

for the $\alpha$-globin genes with the presence of the rare $\alpha^{D}$ (Fig. 1) presented a good opportunity to study the organisation of the related gene cluster by selecting and inbreeding the $\alpha^{D}$ carriers. Previous work showed that the $\alpha^{D}$ allele is a marker for the presence of extra $\alpha$-genes and that the general trend of expression of duplicated $\alpha$-genes was confirmed in the cases of gene triplication and quadruplication for which the $\alpha$-chain output of the downstream genes progressively decreased $[20,22]$. Also in the quadruplicated haplotype, the $3^{\prime}$ gene encoding the 113His-chain appears to have an efficiency of approximately $1 \%$ [9,21]. Parallel investigations at the population level demonstrated that Leccese and Gentile di Puglia, the other two Apulian native sheep breeds, also exhibit a high polymorphism at the $\alpha$-globin gene arrangements with approximately the same frequency of extra-numeral $\alpha$-genes as that in the Altamurana sheep [10,11]. In 1994, Pieragostini et al. [10] also noted that HbD Leccese sheep had a lower packed cell volume (PCV) and haemoglobin content than the common-type sheep.

Our working hypothesis was that the additional $\alpha$-globin genes in sheep may produce extra $\alpha$-globin chains. Consequently, the subjects carrying triplicated or quadruplicated haplotypes may exhibit different hematological phenotypes when compared to the normal duplicated homozygotes. By selecting and inbreeding the above founder Altamurana group, a small flock of homozygotes and heterozygotes for extra $\alpha$-globin genes was set up to carry out the hematological investigation reported in this paper. 
Table I. Nomenclature of sheep genotypes.

\begin{tabular}{|c|c|c|c|}
\hline Gene arrangements & $\begin{array}{c}\text { Running } \\
\text { name }\end{array}$ & $\begin{array}{c}\text { Gene } \\
\text { number } \\
\times \text { haplo- } \\
\text { type }\end{array}$ & $\begin{array}{l}\text { Grouping } \\
\text { as to gene } \\
\text { number }\end{array}$ \\
\hline${ }^{I} \alpha^{L}-^{I I} \alpha^{H} /{ }^{I} \alpha^{L \_}-^{I I} \alpha^{L}$ & $\mathrm{LH} / \mathrm{LL}$ & \multirow{3}{*}{$2 / 2$} & \multirow{3}{*}{$N N(30)$} \\
\hline${ }^{I} \alpha^{A} \_I I \alpha^{H} /{ }^{I} \alpha^{L}-^{I I} \alpha^{L}$ & $\mathrm{AH} / \mathrm{LL}$ & & \\
\hline${ }^{I} \alpha^{A}-^{I I} \alpha^{H} /{ }^{I} \alpha^{A}-{ }^{I I} \alpha^{H}$ & $(\mathrm{AH})_{2}$ & & \\
\hline${ }^{I} \alpha^{L}-^{I I} \alpha^{L}-^{I I I} \alpha^{H} /{ }^{I} \alpha^{L \_I I} \alpha^{L}$ & $\mathrm{LLH} / \mathrm{LL}$ & \multirow{3}{*}{$3 / 2$} & \multirow{4}{*}{$N D(20)$} \\
\hline${ }^{I} \alpha^{D \_}-^{I I} \alpha^{L \_}-^{I I I} \alpha^{H} /{ }^{I} \alpha^{L}-^{I I} \alpha^{L}$ & DLH/LL & & \\
\hline${ }^{I} \alpha^{D \_I I} \alpha^{L}-^{I I I} \alpha^{H} /{ }^{I} \alpha^{A}-^{I I} \alpha^{H}$ & DLH/AH & & \\
\hline${ }^{I} \alpha^{D \_}-^{I I} \alpha^{L} \_I I I \alpha^{L}-^{I V} \alpha^{H} /{ }^{I} \alpha^{L}-^{I I} \alpha^{L}$ & DLLH/LL & $4 / 2$ & \\
\hline${ }^{I} \alpha^{D \_}{ }^{I I} \alpha^{L \_}-^{I I I} \alpha^{H} /{ }^{I} \alpha^{L \_}{ }^{I I} \alpha^{L}-{ }^{I I I} \alpha^{H}$ & DLH/LLH & \multirow{2}{*}{$3 / 3$} & \multirow{4}{*}{$D D(15)$} \\
\hline 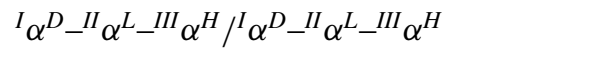 & $(\mathrm{DLH})_{2}$ & & \\
\hline${ }^{I} \alpha^{D}-{ }^{I I} \alpha^{L}-^{I I I} \alpha^{L}-{ }^{I V} \alpha^{H} /{ }^{I} \alpha^{D}-^{I I} \alpha^{L}-{ }^{I I I} \alpha^{H}$ & DLLH/DLH & $4 / 3$ & \\
\hline${ }^{I} \alpha^{D \_}{ }^{I I} \alpha^{L}-{ }^{I I I} \alpha^{L}-{ }^{I V} \alpha^{H} /{ }^{I} \alpha^{D}-{ }^{I I} \alpha^{L}-{ }^{I I I} \alpha^{L}-{ }^{I V} \alpha^{H}$ & DLLH/DLLH & $4 / 4$ & \\
\hline
\end{tabular}

\section{MATERIALS AND METHODS}

\subsection{Nomenclature}

To describe the sheep alpha globin gene alleles, superscripts were placed on the right with the capital letter indicating the relative point mutation: $\alpha^{L}=$ $\alpha^{113 \text { Leu }} ; \alpha^{A}=\alpha^{8 \text { Ser } \rightarrow \text { Ala, } 113 \text { Leu }} ; \alpha^{D}=\alpha^{15 \text { Gly } \rightarrow \text { Asp }, 113 \text { Leu }} ; \alpha^{H}=\alpha^{113 \text { Leu } \rightarrow \text { His }}$. Analogously, the $\alpha$-haplotypes have been described by the sequence of capital letters corresponding to the proper gene (Tab. I).

\subsection{Animals}

From a small Altamurana inbred flock well characterised for globin [20], 30 sheep carrying normal duplicated haplotypes and all possessing the ${ }^{I I} \alpha^{H}$ gene as a marker $(N N)$, were sampled and compared with 35 individuals characterised by extra-numeral $\alpha$-globin gene arrangements. Of these 35 subjects, 20 were heterozygotes carrying either one triple or quadruple chromosome $(N D)$, and 15 had only haplotypes with extra genes $(D D)$ (Tab. I). 


\subsection{Blood analyses}

Blood was sampled in the morning between 6:30 and 8:30, and blood measurements were carried out right after blood sampling.

Cell count (RBC), hemoglobin content $(\mathrm{Hb})$ and packed cell volume (PCV) were measured on red blood cells. Mean corpuscular volume (MCV), mean corpuscular hemoglobin $(\mathrm{MCH})$ and mean corpuscular hemoglobin concentration (MCHC) were calculated. Erythrocytes and leukocytes (WBC) were counted with a standardised automatic counter. The hemoglobin content $(\mathrm{Hb})$ was determined by colorimetry [1] (Tab. II). The erythrocyte fragility test was performed by exposing erythrocytes to hypotonic saline solutions starting from $0.84 \%$ and decreasing by $0.02 \%$ (Tab. III).

\subsection{Qualitative and quantitative analyses of hemoglobin}

The tetramers were analysed by PAGIF [3]. Densitometric evaluation of the $\mathrm{Hb}$ bands was obtained by using a computerised Ultrascan XL enhanced laser densitometer equipped with Gelscan 2.0 software from Pharmacia-LKB (Uppsala Sweden).

\subsection{RP-HPLC}

The globin separation was performed by RP-HPLC using the analytical Vydac large-pore (300 ̊) $\mathrm{C}_{4}$ column (Hesperia, CA), as partly described by Schroeder et al. [15]. The chromatogram was developed with a linear gradient between solvent A ( $20 \%$ acetonitrile - $80 \%$ water containing $0.1 \%$ trifluoracetic acid, TFA) and solvent B (60\% acetonitrile - $40 \%$ water containing $0.1 \%$ trifluoracetic acid, TFA). The gradient was $48 \%-63 \%$ in $100 \mathrm{~min}$ at a flow rate of $1 \mathrm{~mL} \cdot \mathrm{min}^{-1}$. The effluent was monitored at $220 \mathrm{~nm}$. The chromatographic peaks were computed with an LCI 100 computing integrator (Perkin Elmer, Norwalk, CT).

\subsection{Statistics}

The effects of the $\alpha$-globin gene arrangement on the data sets obtained by the hematological examinations were analysed by least-squares analyses of variance. A linear regression analysis of the value of the $\alpha / \beta$ ratio on the number of $\alpha$-globin genes was performed to investigate their relationship.

\section{RESULTS}

\subsection{Hematological profiles}

The hematological profiles of sheep classified on the basis of the $\alpha$-globin gene arrangements are shown in Table II. Significant differences were observed for $\mathrm{RBC}$ and $\mathrm{MCV}$. In both groups, all the parameters fell in the normal 
Table II. Hematological profile in healthy, 2 to 5 years old Altamurana sheep classified on the basis of $\alpha$-globin gene arrangement.

\begin{tabular}{|c|c|c|c|c|c|c|c|c|}
\hline $\begin{array}{l}\alpha \text {-gene } \\
\text { arrangements }\end{array}$ & $\mathrm{N}$ & $\begin{array}{l}\mathrm{PCV} \\
(\%)\end{array}$ & $\begin{array}{c}\mathrm{Hb} \\
\left(\mathrm{g} \cdot \mathrm{dL}^{-1}\right)\end{array}$ & $\begin{array}{c}\mathrm{RBC} \\
\left(\times 10^{6} \cdot \mu^{-1}\right)\end{array}$ & $\begin{array}{l}\mathrm{MCV} \\
\left(\mu^{3}\right)\end{array}$ & $\begin{array}{l}\mathrm{MCH} \\
(\mathrm{pg})\end{array}$ & $\begin{array}{c}\mathrm{MCHC} \\
(\%)\end{array}$ & $\begin{array}{c}\text { WBC } \\
\left(\times 10^{3} \cdot \mu^{-1}\right)\end{array}$ \\
\hline$N N$ & 30 & $31.49 \pm 0.68$ & $10.61 \pm 0.32$ & $8.87^{\mathrm{a}} \pm 0.27$ & $35.90^{\mathrm{a}} \pm 0.10$ & $12.03 \pm 0.05$ & $33.75 \pm 0.76$ & $8.95 \pm 0.75$ \\
\hline$D D$ & 15 & $31.16 \pm 0.63$ & $9.99 \pm 0.29$ & $7.73^{b} \pm 0.24$ & $40.43^{b} \pm 0.09$ & $12.88 \pm 0.04$ & $32.05 \pm 0.70$ & $8.04 \pm 0.67$ \\
\hline
\end{tabular}

Within columns, values with different letters differ $(P<0.05)$.

Table III. Erythrocyte osmotic fragility in healthy Altamurana sheep classified on the basis of $\alpha$-globin gene arrangements: hemolysis percentage (mean \pm s.e.) at different $\mathrm{NaCl}$ concentrations.

\begin{tabular}{lcccccc}
\hline \multirow{2}{*}{$\begin{array}{l}\text { - } \text {-gene } \\
\text { arrangements }\end{array}$} & $\begin{array}{c}\text { number of } \\
\text { individuals }\end{array}$ & \multirow{2}{*}{$\begin{array}{c}\text { observation } \\
\text { per individual }\end{array}$} & \multicolumn{3}{c}{$\% \mathrm{NaCl}$} \\
\cline { 3 - 7 } & & & 0.84 & 0.76 & 0.70 & 0.60 \\
\hline$N N$ & $15^{*}$ & 5 & $4.07 \pm 1.97$ & $12.70 \pm 5.74$ & $54.35^{\mathrm{a}} \pm 8.70$ & $95.49 \pm 1.88$ \\
$D D$ & 15 & 5 & $6.65 \pm 2.00$ & $22.72 \pm 5.80$ & $81.84^{\mathrm{b}} \pm 8.77$ & $97.73 \pm 1.90$ \\
\hline
\end{tabular}

* Only 15 samples were available for this test. Within columns, values with different letters differ $(P<0.05)$. 
range $[4,5]$ except for $\mathrm{RBC}$ of the $D D$ group which revealed a mild anemic condition. In the $D D$ individuals the numerical deficiency of red blood cells was compensated for by the fact that the mean corpuscular volume (MCV) increased by about $12 \%$ as did the mean corpuscular hemoglobin $(\mathrm{MCH})$.

Table III shows that the osmotic fragility of erythrocytes in the $D D$ group was higher than in the $N N$ group at all $\mathrm{NaCl}$ concentrations, but the difference was only significant at the $0.7 \mathrm{NaCl}$ concentration for which the $D D$ group reached $82 \%$ of hemolysis against $54 \%$ for the $N N$ group, which was in the normal range [7].

\subsection{Hemoglobin system analyses}

Specific chromatographic profiles were obtained for different individual gene arrangements as shown in Figures 2 and 3. Table IV provides the findings on the output of $\alpha$-genes inferred from the Hb PAGIF bands and the RPHPLC chromatographic peaks. Overall, it seems that the $5^{\prime}$ gene expressed a decreasing percentage of product as the gene number increased. Table $\mathrm{V}$ shows the output of ${ }^{I} \alpha$ and ${ }^{I I} \alpha$ genes as estimated from the concentrations of different $\alpha$-globin chains on the basis of the densitometric evaluation of their relevant $\mathrm{Hb}$ PAGIF bands in the three genotype groups, and the observed values were compared with the expected values based on previous experiments [20,22]. These data suggest that, on the contrary, there is a surplus of product recorded at the ${ }^{I I} \alpha$ gene level in the triple and quadruple $\alpha$-haplotypes.

The RP-HPLC analysis could not distinguish between the alpha D and the alpha $L$ chains, but this had no consequence on the evaluation of the $\alpha / \beta$ ratio since the total amounts of $\alpha$-globin chains and of $\beta$-globin chains were compared. The association between the number of $\alpha$-globin genes and the $\alpha / \beta$ ratio values is represented by the regression line in Figure 4. The relationship between the two variables was positive and linear. The close fit $\left(\mathrm{r}^{2}=0.967\right)$ obtained by adjusting the regression line was also illustrated by comparing expected $\alpha / \beta$ values with values obtained by integrating globin chain HPLC chromatographic peaks (Tab. VI).

\section{DISCUSSION}

The hematological profile of $D D$ individuals, taken together with the evidence of the increased osmotic fragility of their erythrocytes, seems to be consistent with an accelerated erythrocyte turnover. It is conceivable to ascribe these phenomena to the accumulation of excess, unmatched $\alpha$-globin chains, which was already found to be strongly correlated to the erythrocyte lifespan in humans [23]. 
RBC values and extra $\alpha$-globin genes in sheep

(a)
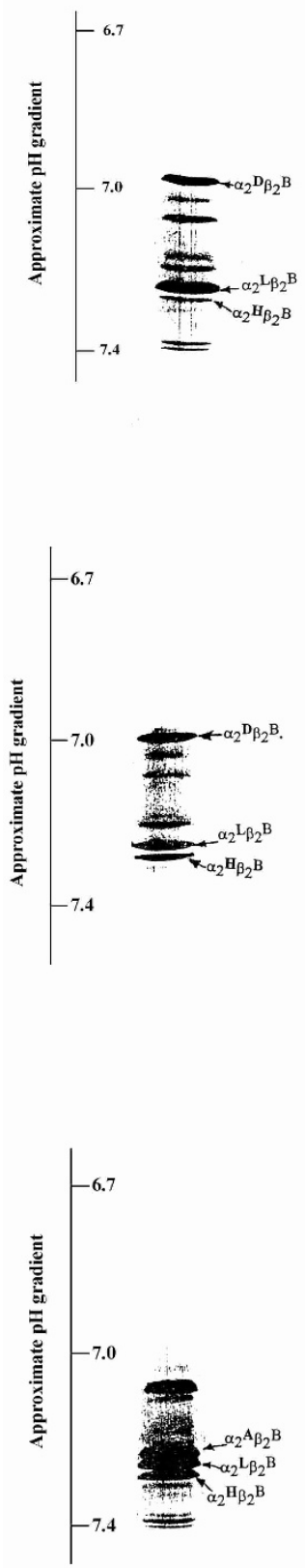

(b)
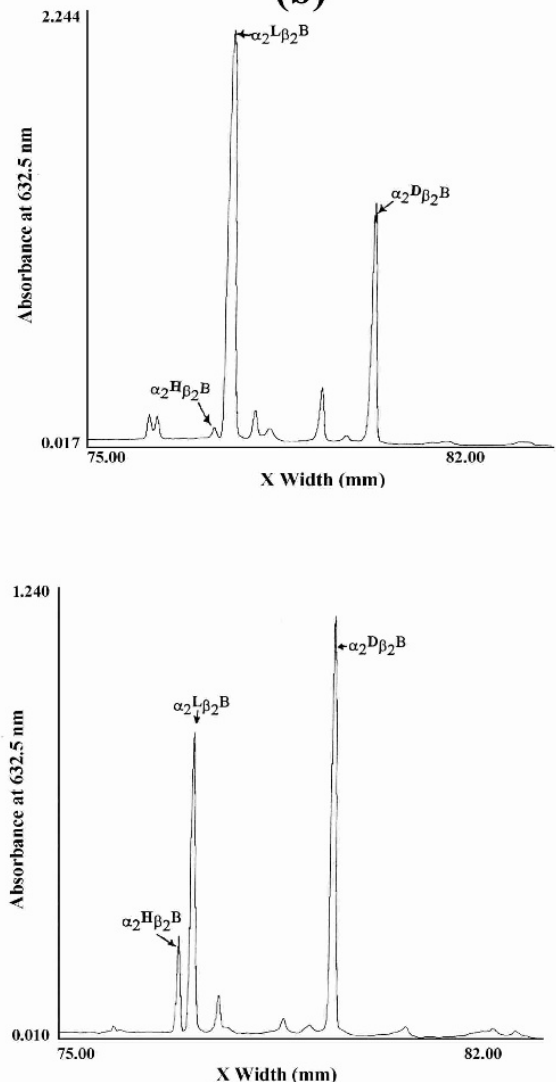

5' 5 ,

D $\frac{1}{\mathrm{D}}$

L L

而

$\mathrm{H}$

$(\mathrm{DLH})_{2}$

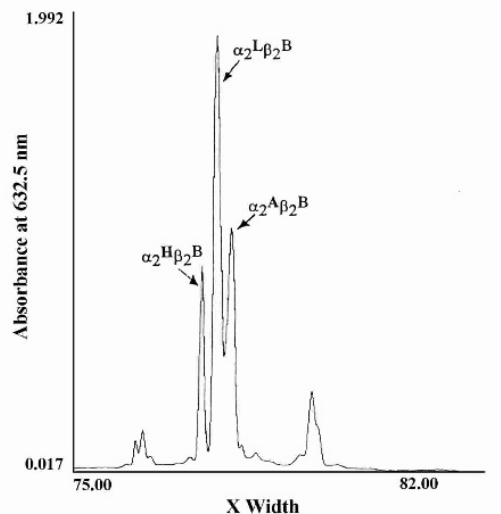

5' 5 ,

A 1 L

$\mathrm{H}$

$\mathrm{AH} / \mathrm{LL}$

Figure 2. $\mathrm{Hb}$ band PAGIF patterns (a) and (b) densitometric profiles in sheep with different gene arrangements. 
Table IV. Output of $\alpha$-globin genes.

\begin{tabular}{|c|c|c|c|c|c|c|}
\hline $\begin{array}{l}\text { Genotype } \\
\text { group }\end{array}$ & $\begin{array}{c}\alpha \text {-globin gene } \\
\text { number }\end{array}$ & observations & $\begin{array}{c}{ }^{I} \alpha \text {-gene } \\
\text { expression }\end{array}$ & $\begin{array}{l}{ }^{I I} \alpha \text {-gene } \\
\text { expression }\end{array}$ & $\begin{array}{l}{ }^{I I I} \alpha \text {-gene } \\
\text { expression }\end{array}$ & $\begin{array}{l}{ }^{I V} \alpha \text {-gene } \\
\text { expression }\end{array}$ \\
\hline$N N$ & $2 / 2=4$ & 30 & $32.2 \pm 0.49^{*}$ & $17.6 \pm 0.35$ & - & - \\
\hline \multirow{2}{*}{$N D$} & $3 / 2=5$ & 13 & $30.4 \pm 0.86$ & $15.4 \pm 0.76$ & $6.1 \pm 0.28$ & - \\
\hline & $4 / 2=6$ & 7 & $30.2 \pm 1.07$ & n.d. & n.d. ${ }^{\dagger}$ & $1.4 \pm 0.23$ \\
\hline \multirow{3}{*}{$D D$} & $3 / 3=6$ & 9 & $29.1 \pm 0.71$ & $16.4 \pm 0.47$ & $5.3 \pm 0.30$ & - \\
\hline & $4 / 3=7$ & 4 & $28.45 \pm 0.91$ & n.d. & n.d. & n.d. \\
\hline & $4 / 4=8$ & 2 & $27.82 \pm 0.82$ & n.d. & n.d. & $1.5 \pm 0.34$ \\
\hline
\end{tabular}

${ }^{*}$ All the data in the table are expressed as mean values \pm standard error. ${ }^{\dagger}$ n.d. $=$ non-detectable the same chain being produced by more than one gene in different positions. 
RBC values and extra $\alpha$-globin genes in sheep
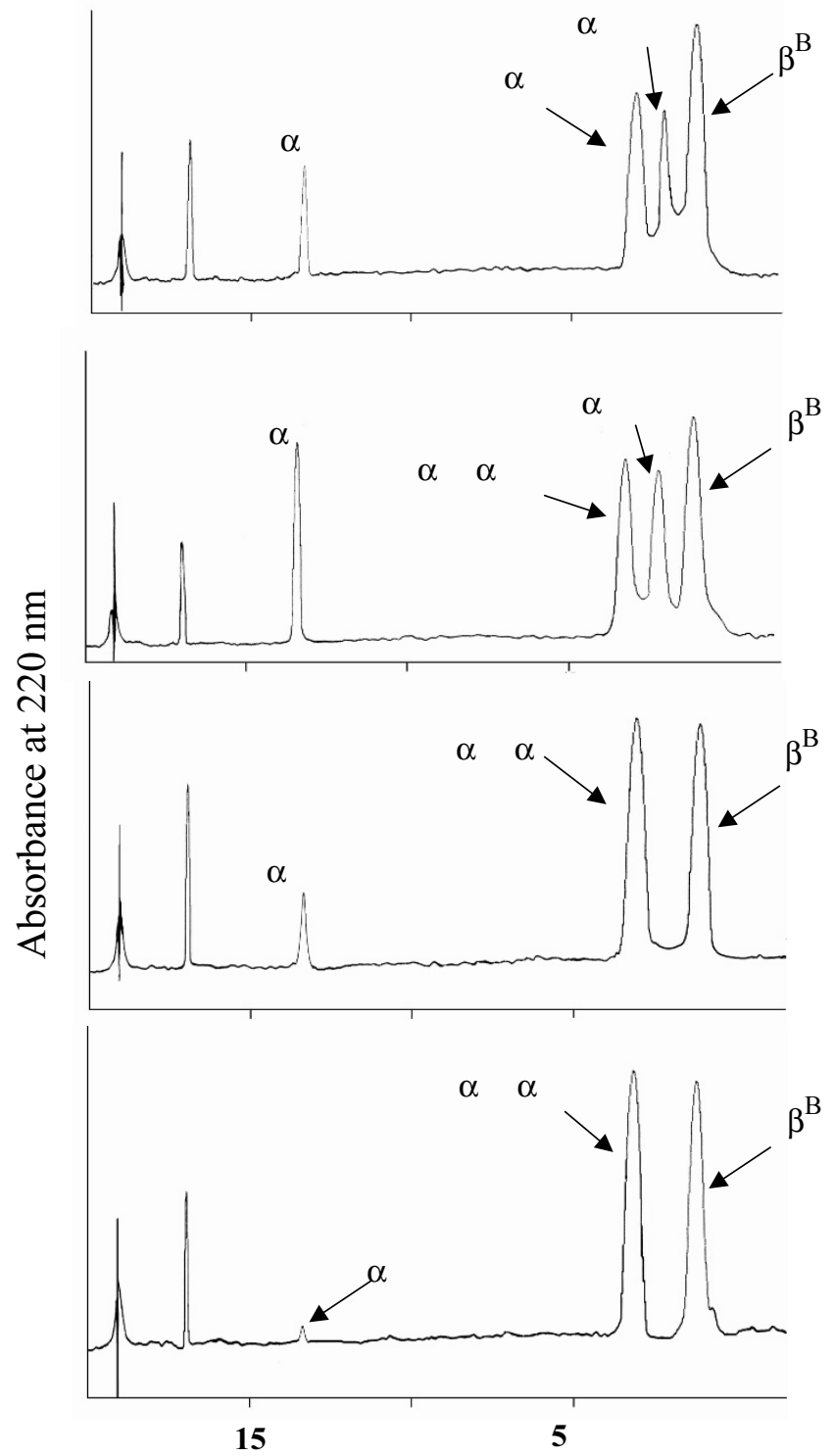

Figure 3. HPLC specific chromatographic profiles of different individual gene arrangements. The concentration of each single $\alpha$-globin peak expressed as a percentage of the total amount of $\alpha$-globin chains is indicated in parentheses.

It is generally accepted that the presence of unpaired excess globin chains is the primary circumstance leading to membrane alterations that result in the premature destruction of red cells in thalassemia $[13,14,26]$. 
Table V. Output of ${ }^{I} \alpha$ - and ${ }^{I I} \alpha$-globin genes.

\begin{tabular}{lcccccccc}
\hline & & \multicolumn{3}{c}{${ }^{I} \alpha$-globin gene expression* } & & \multicolumn{3}{c}{${ }^{I I} \alpha$-globin gene expression* } \\
Genotype & $\mathrm{N}$ & Obs. & Exp. & Deviation & & Obs. & Exp. & Deviation \\
\hline$N N$ & 30 & 32.2 & 32 & $+0.20 \pm 0.39$ & & 17.55 & 18 & $-0.45 \pm 0.07$ \\
$N D$ & $13^{\dagger}$ & 30.0 & 32 & $-2.03 \pm 0.62$ & & 14.43 & 12 & $+2.57 \pm 1.35$ \\
$D D$ & $9^{\dagger}$ & 29.1 & 32 & $-2.90 \pm 0.54$ & & 16.39 & 12 & $+4.39 \pm 0.47$ \\
\hline
\end{tabular}

* Observed values (Obs.), corresponding expected values (Exp.) [20,22], and deviation from the expectation. ${ }^{\dagger}$ Only triple arrangements allow the detection of the ${ }^{I I} \alpha$-globin gene expression.

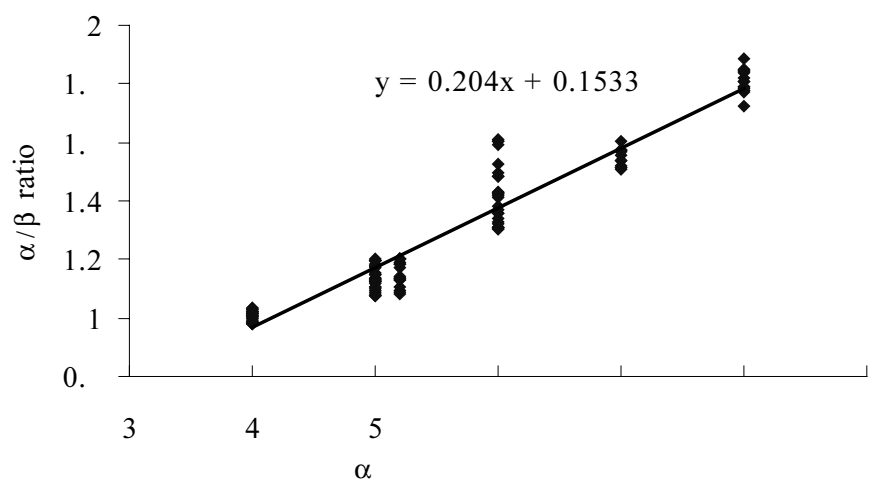

Figure 4. Linear regression of the $\alpha$-and $\beta$-chain ratio (Y) on the number of copies of the $\alpha$-globin gene $(\mathrm{X})$.

Table VI. Alpha and beta globin chain ratio $(\alpha / \beta)$ in Altamurana sheep carrying different numbers of $\alpha$-globin genes.

\begin{tabular}{lccccc}
\hline $\begin{array}{l}\alpha \text {-gene } \\
\text { arrange- } \\
\text { ments }\end{array}$ & $\begin{array}{c}\alpha \text {-globin } \\
\text { genes } \\
\text { copies }\end{array}$ & Subjects & $\begin{array}{c}\text { HPLC } \\
\text { chromato- } \\
\text { gram per } \\
\text { subject }\end{array}$ & $\begin{array}{c}\alpha / \beta \text { values } \\
\text { observed } \\
(\overline{\mathrm{x}} \pm \text { s.e. })^{*}\end{array}$ & $\begin{array}{c}\alpha / \beta \\
\text { values } \\
\text { calculated }\end{array}$ \\
\hline $2 / 2$ & 4 & 30 & 1 & $1.005 \pm 0.021$ & 0.99 \\
$3 / 2$ & 5 & 13 & 2 & $1.145 \pm 0.035$ & 1.17 \\
$4 / 2$ & 6 & 7 & 3 & $1.190 \pm 0.048$ & 1.21 \\
$3 / 3$ & 6 & 9 & 3 & $1.424 \pm 0.059$ & 1.35 \\
$4 / 3$ & 7 & 4 & 3 & $1.517 \pm 0.038$ & 1.50 \\
$4 / 4$ & 8 & 2 & 3 & $1.660 \pm 0.045$ & 1.71 \\
\hline
\end{tabular}

* Mean values and standard error of observed values (obtained by integrating globin chain HPLC chromatographic peaks) to be compared to the $\alpha / \beta$ values calculated on the basis of the best fit curve. 
In humans, the presence of extra copies of $\alpha$-globin genes has often been shown to worsen the degree of anemia in $\beta$-thalassemia heterozygotes $[6,18]$. Sorensen et al. [17] quantified and characterised the membrane skeletalassociated globin in normal, transgenic thal/sickle, and thalassemic mice and showed that only $\alpha$-globin was associated with the membrane skeleton in the pathologic red blood cells. Excess $\alpha$-chains cannot form homotetramers and, upon synthesis, rapidly bind to the cytoplasmic side of the $\beta$-thalassemic red cell membrane, even in young erythroblasts [25]. Moreover, model $\beta$-thalassemic RBC, prepared by introducing excess $\alpha$-globin in the cell, have shown to exhibit structural and functional changes, which are almost identical to those observed in $\beta$-thalassemic cells [16]. The pathological abnormalities and the subsequent effects on the morphology and function of the thalassemic RBC stem from the alteration of the synthetic ratio between the globin chains $(\alpha / \beta)[12,24]$.

The overall blood picture of $D D$ individuals seems to mimic a thalassemialike syndrome in sheep. In the beta thalassemia syndrome one of the outstanding features is hemoglobin deficiency - due to the reduced synthesis of $\beta$-globin chains - and the consequent microcytosis, but the hematological phenotype of the $D D$ sheep was characterised by normal $\mathrm{Hb}$ values and macrocytosis. In this case, the increased MCV values may be ascribed to the presence of a higher proportion of younger cells and thus symptomatic of the already mentioned accelerated turnover. In the human form of heterozygous $\beta$-thalassemia the ratio $(\alpha / \beta)$ ranges from 1.5 to 2.5 , whereas the normal value is $1[2,23]$. This corresponds to thalassemia minor with small red cells and mild anemia. In the present investigation, the $\alpha / \beta$ ratio was found to range on average from $1.0 \mathrm{in}$ $N N$ individuals to 1.2 in $N D$ and 1.6 in $D D$ subjects, and the imbalance was not due to a deficiency of the $\beta$ chain but to a surplus of the $\alpha$ chains because of extranumerary $\alpha$-genes. Moreover the $D D$ hematological phenotype was not associated to any clinical symptoms and may be regarded as a mere example of the variability of the hemoglobin system.

Phenotypic variability of hemoglobin, however, may also be induced by hemoparasites. The high number of hemoglobinopathies in human populations living in endemic malaria areas is one of the most dramatic examples. The red cell is a remarkable example of Darwinism in action, and it is not surprising that genetic changes in the red cells may affect the success of the intraerythrocytic life of parasites [5].

As far as the Apulian sheep are concerned, they show the ability to thrive in endemic tick-borne disease (TBD) areas, naturally developed over a period of many centuries. Although epidemiological studies on the presence of tick borne pathogens in Apulian sheep are lacking, repeated random sampling in the different areas of Apulia (data not shown) constantly allowed the identification of these parasites without detecting clinical signs of disease. Apulian native sheep show a breed-related aptitude to remain in good health and to reproduce 
while harbouring tick borne pathogens. Indeed, Altamurana sheep infected with Babesia ovis are able to control parasitemia and compensate the effects of anaemia into a benign macrocytic and hyperchromic form. There is also evidence that the local sheep breeds cope with anoxemic stress by producing red globules enriched with hemoglobin and accelerating the turnover of older and less efficient red blood cells [8].

In our opinion, the findings of this investigation should be considered in the light of the tolerance that the Apulian sheep have developed toward TBDs. The alterations recorded in $D D$ red blood cells may produce an unfavourable environment for the parasites. Accordingly, the high frequency of extranumerary haplotypes may be the result of a selective advantage of the corresponding phenotypes in endemic TBD areas.

\section{ACKNOWLEDGEMENTS}

The authors wish to acknowledge Athina Papa for revising the English of the manuscript.

\section{REFERENCES}

[1] Bostedt H., Mayer B., Über die Enwicklung des roten Hämogrammes bei Lämmern in den ersten Lebenwochen unter natürlichen und artifiziellen Aufzuchbeddingungen, Berl. Münch. Tierärztl. Wschr. 89 (1976) 1215-1216.

[2] Chalevelakis G., Clegg J.B., Weatherall D.J., Imbalanced globin chain synthesis in heterozygous beta-thalassemic bone marrow, Proc. Natl. Acad. Sci. USA 72 (1975) 3853-3857.

[3] Di Luccia A., Iannibelli L., Pieragostini E., Ferrara L., Phenotyping of all sheep haemoglobin morphs, Small Rum. Res. 7 (1992) 189-194.

[4] Jain M.C., Shalm's Veterinary Hematology, Lea and Febinger Publ., Philadelphia, 1986.

[5] Luzzato L., About hemoglobins, G6PD and parasites in red cell, Experiencia 51 (1995) 206-208.

[6] Ma S.K., Au W.Y., Chan A.Y., Chan L.C., Clinical phenotype of triplicated alphaglobin genes and heterozygosity for beta 0 -thalassemia in Chinese subjects, Int. J. Mol. Med. 8 (2001) 171-175.

[7] Oyewale J.O., Osmotic fragility of erythrocytes of west African dwarf sheep and goats: effects of temperature and pH, Br. Vet. J. 147 (1991) 163-170.

[8] Pieragostini E., Petazzi F., Genetics and tolerance to tick-borne diseases in South Italy: experience in studying native Apulian and exotic sheep breed, Parassitologia 41, Suppl. 1 (1999) 89-94.

[9] Pieragostini E., Di Luccia A., Vincenti D., Sheep hemoglobin polymorphism: densitometric evaluation of IEF profiles, in: Proceedings of the 23th Conf. ISAG, 3-7 August 1992, Anim. Genet. 23, Suppl. 1, p. 28.

[10] Pieragostini E., Dario C., Bufano G., Haemoglobin phenotypes and hematological factors in Leccese sheep, Small Rum. Res. 13 (1994) 177-185. 
[11] Pieragostini E., Di Luccia A., Rullo R., Alpha and beta globin gene polymorphism in Gentile di Puglia sheep, in: Proceedings of the 24th National Congress of The Scientific Association of Animal Production (ASPA), 12-15 June 2001, Vol. 24, University of Firenze, Firenze, pp. 91-93.

[12] Rachmilewitz E., Oppenheim A., Shalev O., The red blood cell in thalassemia, in: Nagel R.L. (Ed.), Genetically abnormal red cells, CRC Press, 1988, Vol. 1, pp. 137-160.

[13] Schrier S.L., Rachmilewitz E., Mohandas N., Cellular and membrane properties of alpha and beta thalassemic erythrocytes are different: implication for differences in clinical manifestations, Blood 74 (1989) 2194-2202.

[14] Schrier S.L., Mohandas N., Globin-chain specificity of oxidation-induced changes in red blood cell membrane properties, Blood 79 (1992) 1586-1592.

[15] Schroeder W.A., Shelton J.B., Shelton J.R., Huynh V., Teplow D.B., High performance liquid chromatographic separation of the globin chains of non-human hemoglobins, Hemoglobin 9 (1985) 461-482.

[16] Scott M.D., Entrapment of purified alpha-hemoglobin chains in normal erythrocytes as a model for human beta-thalassemia, Adv. Exp. Med. Biol. 326 (1992) 139-148.

[17] Sorensen S., Rubin E., Polster H., Mohandas N., Schrier S., The role of membrane skeletal-associated alpha-globin in the pathophysiology of beta-thalassemia, Blood 75 (1990) 1333-1336.

[18] Thompson C.C., Ali M.A., Vacovsky M., Boyadjian S., The interaction of anti 3.7 type quadruplicated alpha-globin genes and heterozygous beta-thalassemia, Hemoglobin 13 (1989) 125-135.

[19] Vestri R., Salmaso S., Further evidence supporting the hypothesis of the duplication of the hemoglobin alpha-chain locus in sheep, Biochem. Genet. 19 (1981) 895-900.

[20] Vestri R., Pieragostini E., Yang F., Di Gregorio P., Rando A., Masina P., Expression of triplicated and quadruplicated alfa globin genes in sheep, Br. J. Haematol. 77 (1991) 110-116.

[21] Vestri R., Pieragostini E., Manca L., Masala B., Detection by revesed-phase HPLC of trace amount of the $\alpha^{113 \text { His }}$ globin chain in a sheep homozygous for a quadruple $\alpha$-globin gene chromosome, Int. J. Biochem. 25 (1993) 1939-1941.

[22] Vestri R., Pieragostini E., Ristaldi M.S., Expression gradient in sheep alpha alpha and alpha alpha alpha globin gene haplotypes: mRNA levels, Blood 83 (1994) 2317-2322.

[23] Vigi V., Volpato S., Gaburro D., Conconi F., Bargellesi A., Pontremoli S., The correlation between red-cell survival and excess of alpha-globin synthesis in beta-thalassemia, Br. J. Haematol. 16 (1969) 25-30.

[24] Weatherall D.J., Clegg J.B., The Thalassaemia Syndromes, Blackwell Scientific, Oxford, 1981.

[25] Wilairat P., Kittikalayawong A., Chaicharoen S., The thalassemic red cell membrane, Southeast Asian J. Trop. Med. Public Health 23, Suppl. 2 (1992) 74-78.

[26] Yuan J., Bunyaratvej A., Fucharoen S., Fung C., Shinar E., Schrier S.L., The instability of the membrane skeleton in thalassemic red blood cells, Blood 86 (1995) 3945-3950. 